\title{
THE LINKS BETWEEN THE NEW ROMANIAN CIVIL CODE'S PROVISIONS AND THE ONES OF LAW NO. 25/2012
}

\author{
C. S. Jucan
}

\section{Codruța-Ştefania Jucan}

Associate Lecturer, $\mathrm{PhD}$.

"Dimitrie Cantemir" Christian University, Bucharest

Faculty of Law, Cluj-Napoca

*Correspondence: Codruța-Ştefania Jucan, "Dimitrie Cantemir" Christian University, Faculty of Laws, No. 2 Burebista Street, Cluj-Napoca, Romania

Email: stefania.jucan@yahoo.com

\begin{abstract}
The present paper aims at offering a brief view into the newly provisioned regulations regarding domestic violence in Romanian Law. With this purpose in mind, the author invokes past regulations and present realities, correlating them with the novelty of the New Civil Code and the last modifications of Law No. 25/2012. The result is a general study that points out the main characteristics and instruments employed by the new legal framework in combating domestic violence.
\end{abstract}

Keywords: domestic violence, New Civil Code, Law. No. 25/2012, Family Law.

\section{Introduction}

The current year - 2012 - has brought on a series of legislation novelties, not necessarily innovations, especially imitations from other states' juridical systems. In the present study we will try to analyze the modality in which these Family Law provisions of the New Civil Code are structured and completed by the new juridical norms that regulate family violence. The last ones are condensed in Law No. 25/2012 which has significantly modified Law No. 217/2003 for combating and preventing family violence. The lawmaker has seriously tackled this problem, considering it to be one of national interest, this especially standing out within the legal text, the main reason for this being that unfortunately Romania is holding some negative records in that which regards family violence.

\section{The History of the Problem}

Without detailing what other authors have already pointed out, we observe that domestic violence not only was not regarded to be a problem for a long time but in certain historical eras it was considered to be even justified, from Antiquity to the Modern Age being if not encouraged, at least justified or explained. In the worst case, some minor reproof was applied to the one implicated, not without drawing the attention of the wounded party on its own culpability, all under the dome of the Church's Canonical Law.

The pre-1990 legislation has totally neglected and occulted the problems of the Romanian society, a patriarchal one by excellence. Only in 1990 the quality of being a family member was considered to be an aggravating circumstance in the penal provisions and a special law that would address domestic violence, Law. No. 217/2003 ${ }^{1}$ was much later

\footnotetext{
${ }^{1}$ For an analysis of Law No. 217/2003 see Mariana Narcisa Radu, Mihnea Radu, Considera $\square$ ii privind legea pentru prevenirea şi combaterea violenței în familie in Studii şi cercetări din domeniul ştiințelor socio-umane, Academia Română, Filiala Cluj-Napoca, vol. 12, Ed. Argonaut, Cluj-Napoca, 2004, p. 409-413.
} 
adopted, even though at present times, the situation is especially grave, requiring normative adjustments ${ }^{2}$.

As we have shown from a statistical point of view, Romania's situation is a challenged one regarding this issue. Of course, statistics have their limits but this certainly reveals real aspects relating to the ever more active concern of the public institutions to identify the phenomenon. The policy of the European Union follows the same direction in the conditions in which it was statistically proven that half of the women and children (the most abused categories) from Europe are victims of domestic violence ${ }^{3}$. The data made available by the Ministry of Labor, Family and Social Protection are more than worrisome from a statistical point of view, the figures from 2008 and 2009 indicating 11534 cases (137 deaths) $)^{4}$, respectively 9868 cases ( 77 deaths) in the first 9 months of $2009^{5}$. The tendency is one of elevation of this phenomenon, the reports forwarded by the same ministry to the „No Abuse” Association indicating 11.000 cases for 2010, the centralized results not being publicly released yet ${ }^{6}$.

There are multiple forms of violence and we will only mention them because we do not wish to insist on the forms of violence managed exclusively through the penal legislation. Even Law No. 217/2003, as it was modified by Law No. 25/2012 concretely defines in article 4 letters a) - g) the manifestations of domestic violence: verbal, psychological, physical, sexual, economic and social.

The concrete definition of the notion of „family member” is also important and it too has taken on new meanings as a result of the provisions of the new legislation?

\section{The Inter-Disciplinary character of The Domestic Violence Issue}

In these conditions, taking in account the figures presented and the fact that over $50 \%$ of Romanians considers that domestic violence is normal, it was only normal that ever more severe measure be taken ${ }^{8}$.

Next to the juridical aspects that are evidently linked to the existence of a normative act, this law has a powerful inter-disciplinary character, its application requiring the instrumentality of an important number of public institutions.

Of course, The Ministry of Administration and Internal Matters and The Ministry of Justice have essential competencies in that which regards the application of this law. We must also underline its powerful social component, The Ministry of Labor, Family and Social Protection being expressly designated as one of the institutions directly implicated in managing the policies of social assistance and that it is also responsible with the financial dimension of the programs resulted from the application of this law.

Domestic violence is not only a juridical problem, it has numerous dimensions that link it with psychology, social assistance, social phenomena ${ }^{9}$, all of these corroborated with theoretical issues, purely speculative but important to the matter at hand ${ }^{10}$.

\footnotetext{
${ }^{2}$ Maria Pescaru, Preventing and Fighting against (intra)Family Violence in Agora International Journal of Juridical Sciences, 2011, no. 2, p. 201-206.

3 http://www.ziare.com/stiri/violenta/un-sfert-din-femeile-si-copiii-din-europa-victime-ale-violentei-1148779 article and statistics from the $3^{\text {rd }}$ of Feb. 2012 consulted on the $9^{\text {th }}$ of Oct. 2012.

4 http://www.mmuncii.ro/pub/imagemanager/images/file/Statistica/Buletin\%20statistic/2009/familie1_65.pdf consulted on the $9^{\text {th }}$ of Oct. 2012.

5 http://www.mmuncii.ro/pub/imagemanager/images/file/Statistica/Buletin\%20statistic/2009/familie4_68.pdf consulted on the $9^{\text {th }}$ of Oct. 2012.

6 http://www.ziare.com/stiri/violenta/romania-peste-11-000-de-cazuri-de-violenta-in-familie-in-2010-1136095 consulted on the $9^{\text {th }}$ of Oct. 2012.

${ }^{7}$ Mariana Narcisa Radu, Mihnea Radu, The Concept of „Family Member” in the Romanian Penal Legislation in Valahia University Law Study, vol. XVIII, no. 2, 2011, p. 48-52.

${ }^{8} \mathrm{http} / /$ www.ziare.com/stiri/violenta/jumatate-dintre-romani-considera-ca-violenta-fizica-in-familie-este-cevanormal-1087884 - article featured on the $12^{\text {th }}$ of Apr. 2011, consulted on the $8^{\text {th }}$ of Oct. 2012.
} 
A true campaign has started several years ago, its purpose being stopping or at least reducing the phenomenon, starting from a preventive function. Next to numerous NGOs that greatly contribute to the support of the victims of these abuses (ex. The „Artemis" Centre), The Institute of Prevention and Combating of Crime has started an ample program closely related with domestic violence ${ }^{11}$.

\section{Correlations with other juridical norms}

Because of the magnitude of the phenomenon and its numerous implications, the desired solution would be the existence of conjoined legislations that would jointly function from within several Legal branches in order to assure resolution of the problems linked to domestic violence.

Firstly, one must observe certain provisions of the New Civil Code that have a strong tendency towards the linkage with penal norms in certain matters rather than the current approach that, up until now had preferred to remain within the specific framework of Civil Law.

Evidently, the most significant implications of this normative act - Law No. 217/2003, as it was modified by Law No. 25/2012 - are juridical linked to Penal Law, respectively to the Penal Code and Penal Procedural Code. At the same time, we are dealing with a Penal normative act that presumes a series of specific elements - the urgency of the measures, the participation of the Public Ministry in managing these situations and also the temporary „crisis" character of some of them, the solutions applied being always temporary.

Thusly, several types of institutions were developed, like centers of urgently receiving the victims, centers of combating violence and centers for aggressors and the last novelty brought on by the last modification of the law regarding the prevention and combating domestic violence is the possibility of obtaining a restraining order ${ }^{12}$.

In order to support the efficiency of these norms or at least the fact that a timid start exists, several actions forwarded with the purpose of instituting this measure were noticed even at the date of the entering in effect ${ }^{13}$ of the provisions at hand.

The Correlation of the Legislation Regarding Domestic Violence with the Family Law Norms of The New Civil Code

The big problem appears in the moment in which, after the disappearance of the urgent element determined by the imminence of the peril, even though the restraining order exists, more concrete and durable norms would have to be applied. This is because the situation of the victim cannot be solved exclusively by Penal Law special procedures, even though constraints on the liberty of the aggressor (which at the moment happens as a last resort situation at most) as long as these measures are not supported by social assistance, psychological counseling and patrimonial measures.

In this regard, coordination between the Penal Law norms, those regarding social assistance and civil norms would have to exist.

\footnotetext{
${ }^{9}$ An interesting article on this subject, author Otilia Sava, on the 31st of March 2012 http://www.avocatnet.ro/content/articles/id 28240/De-ce-acceptam-violenta-domestica.html consulted on the $9^{\text {th }}$ of Oct. 2012.

${ }^{10}$ Corina Buzdugan, Teoria generală a dreptului, Ed. Universul Juridic, Bucharest, 2011, passim; eadem, Theories of the Right of the State to Impose the Legal Sanction in Criminal Matters în The Efficiency of Legal Norms, Hamangiu Publishing House, Bucharest, 2012.

${ }^{11} \mathrm{http}: / /$ www.politiaromana.ro/prevenire/ - consultat la data de 8 oct. 2012 (not adapted to the new legal provisions).

12 Mirela Gorunescu, 13th of July 2012 http://www.juridice.ro/209698/ordinul-de-protectie-in-legislatiaromaneasca.html consulted on the $9^{\text {th }}$ of Oct. 2012.

${ }^{13}$ http://www.telegrafonline.ro/1339448400/articol/201992/victimele violentei in familie cer_protectie impotri va agresorilor.html consulted on the $8^{\text {th }}$ of Oct. 2012.
} 
We do not know if the state realized the importance of such a correlation and if it intends to continue along these beneficial lines, beyond the small signs that stood out in this sense. However, it appears to be certitude that in the actual form of the Civil Code, some of the provisions relating to family rapports and beyond can become useful in these situations.

The whole Chapter II of The New Civil Code, respectively article 58 and the next one, refers to a problem that is directly linked to those already discussed - The respect owed to the human being and its inherent rights. It is evident that in the case of domestic violence, through the introduction of these new provisions the law is broken twofold, both from a Civil and Penal perspective. Both the doctrine (which has analyzed these rights before their express mentioning in the current Civil $\mathrm{Code}^{14}$ ) and the law recognize the "right to life, health, physical and psychological integrity, dignity, to an own image, respect of private life as well as other similar rights recognized by law" (according to art. 58) ${ }^{15}$ as being non-transmissible, inherent. Inaccessible, un-patrimonial, in-sesizable and imprescriptible rights. "Life, health and the physical and psychological integrity are rights guaranteed and equally upholded by the law" (article. 61 as well as art. 64 referring to the inviolability of the human body) are primarily rights that refer to the welfare of society, according to the same article, second paragraph.

Of course, in the next articles the Code refers to the eugenic practices developed due to modern technology. Also, the new provisions make the intimation of the Court possible, in the conditions of articles 252-256, in order to dispose the reparation of the material and moral damages suffered as a result of breaching the aforementioned provisions, the legal civil delictual responsibility being invoked. Of course, at least for this part of the provisions, the procedure that can be initiated by the victim is easier, faster, advantageous and more beneficial if started within a Penal trial.

Aspects like infringement of the rights to private life, image, dignity (art. 71-73 with the definitions and examples of art 74) were linked to Civil Law (although not entirely or at least arguable).

For the protection of the minor and not only in this case, more concrete norms are provisioned a little different, especially regarding the procedure, the institution of Tutelage and Curatorship (art. 104 and the next one). In a certain measure, the old norms were kept, provisioned both by civil legislation and by especially applicable juridical norms, respectively Law No. 272/2004. These norms, on which we will not insist, also regulate the situation in which the institution of the Tutelage or Curatorship is imposed on the child, when the parents do not respect their obligations and more so when the children become victims of domestic violence, the statistics indicating them to be the perfect victims, next to the women and the old. All these measures are under the control and strict observation of the Tutelage Court, which will be the one to watch over the upholding of the rights of those under Tutelage. Of course, these institutions could make the subject of a distinct paper on their own, reason because of which we will not develop the subject further as it is only auxiliary to the present study.

There are some totally new consistent provisions which directly regard the family relations, now provisioned in the content of the Civil Code.

The correlative rights and obligations of the spouses are regulated in the IInd Book of the Code, Chapter V, art. 307 and the next one.

One of the obligations expressly provisioned is that of mutual respect, according to art. 309 paragraph 1, respect which the doctrine has indicated to be the respect of the person and personality of the other spouse, including his or her private life, without the censorship of

\footnotetext{
${ }^{14}$ Călina Jugastru, Reflecții asupra noțiunii şi evoluției drepturilor personalității, An. Inst. de Ist. „G. Barițiu”, Cluj-Napoca, Series Humanistica, vol. V, 2007, p. 325-340.

${ }^{15}$ Noul Cod civil. Comentariu pe articole, coord. Fl. A. Baias etc., C.H. Beck Publishing House, 2012, p. 58 sqq.
} 
mail, social relations or professional choices, according to art. $310^{16}$, which regulates the independence of the spouses at a personal level, through relating to the principle of codecision within marriage. Evidently, if we try to corroborate all the possible types of violence applied within a family between the spouses, there are as many breaches of the general civilian provisions as there are of the special law.

Beyond the personal rights and obligations, the two spouses also have rights and obligations of a patrimonial nature. Within these types of rapports, certain types of violence can be observed, like psychological, economic, social and spiritual, without excluding the other forms. Frequently, the aggressive spouse abuses the lack of control of the other over the family goods or the poor material state with which the whole family is confronted in order to maintain his or her dominant position. In this regard, the case of wives that cannot or refuse to divorce because they fear especially expensive and endless trials that they do not afford is very frequent

The new provisions permit the possibility that in certain special situation, a special judiciary mandate or temporary tutelage can be instituted over one of the spouses when he or she puts the family at risk through his or her own acts, provisions which we can easily correlate with an abusive behavior caused by alcohol consumption or the consumption of other substances (art. 315, 316).

One of the great novelties is the provision of art. 318 of the New Civil Code, which regulates the right of information between the spouses and the obligation of spouses to inform the other relating to the goods, revenues and debts. In case of the contrary and lack of knowledge on behalf of third parties, a relative presumption is instituted according to which the plaintiff spouse tells the truth.

Inspired not only by the former legislation but also by situations of an abusive nature from the practice of the Courts, the possibility of recording immovable property as a family residence has been instituted even if the respective spouse is not the proprietor of the house, which assures an elevated protection of the family over the whole duration of the marriage. If these provisions are corroborated with the possibility of obtaining a restriction order or one of evacuating the abusive husband from the house these add up to especially useful norms in limiting the effects of abuse ${ }^{17}$. Furthermore, according to the provisions of art. 322 of the New Civil Code, even the juridical acts concluded regarding that immovable property have a special legal character according to which the consent of the other spouse is needed, even if the spouse that concludes the acts is sole proprietor. As a result, the act can be annulled (if the immovable property was properly noted in the Land Register) or damages can be requested (if there is no such inscription in the Land Register). ${ }^{18}$

There are similar provisions regarding tenancy (art. 323 of the New Civil Code).

The two spouses are obligated to award reciprocal material support and as a novelty, what the jurisprudence already established is now regulated, respectively the assessment of the work that each spouse has made within the household, adding a value to the work of the spouses (the law does not distinguish between the spouses but the work of women within the household is still predominant within the Romanian family, according to the aforementioned statistics and to the social realities) ${ }^{19}$. At the same time, the right of compensation for this spouse is instituted, if his or her help surpassed the normal limits (art. 328). These are normal provisions, extremely atypical for the Romanian society but which come to realize a certain equilibrium within the families. Without presenting polarized values, at a national level the

\footnotetext{
${ }^{16}$ Idem, p. 316-319.

${ }^{17}$ Mirela Gorunescu, art. cit.

${ }^{18}$ Noul Cod civil. Comentariu pe articole, coord. Fl. A. Baias etc.,C.H. Beck Publishing House, 2012, p. 334340.

${ }^{19}$ Idem, p. 347.
} 
reality is that the revenues of working women are lower than those of their male colleagues that hold the same positions or when this discrimination does not exist, there is a clear preference for male employees.

A true Pandora's box has been opened for both the parties of a marriage through the acceptance of the existence of several matrimonial regimes and the possibility of concluding some matrimonial conventions by the future spouses. We will not insist on these aspects, we will only mention them, taking in account that their link to the subject of the paper is indirect and they have already been the subject of some specialized studies ${ }^{20}$.

Also, the partition of the patrimony becomes possible within marriage, without the disappearance of the legal community of goods (if this is chosen by the spouses), according to art. 358 of the New Civil Code, which is a welcomed provision, taking in account that the old regulations requested special conditions and justified situations in order to request this kind of partition. Presently, any spouse can request the administration of a part of the goods or the individualization of his or her quota, independently of the marriage.

Continuing on the same line of thought, the provisions regarding the separation of patrimonies which bears similar characteristics strengthen this approach, the only difference being that in the moment of choosing this option the regime of the community of goods ceases to exist for future goods. Also, the spouse that requests this separation must prove the culpability in administering the goods on behalf of the other spouse, condition that is not necessary in the situation of the partition of goods.

Finally, other significant aspects are those related to the decomposition of marriage that comes as auxiliary elements.

From the provisions of art. 373 paragraph B corroborated with art. 379, 384, and 390 of the New Civil Code, the decomposition of marriage because of the culpability of a spouse attracts, if the marriage in question took longer than 20 years, the possibility of obtaining a compensation charge in order to avoid a lack of equilibrium in the living conditions. This sum of money is established according to several factors (resources of spouses, health, effects of divorce etc.) and can take on the form of a global fixed sum or a monthly allowance, percentage quotas of the debtor's revenues or the beneficial interest of mobile or immovable goods (art. 391, 392 and the next of the New Civil Code). ${ }^{21}$

At the same time, adding to the possibility of requesting the compensation charge, in case of the divorce from the culpability of the spouse there is also a possibility to request the allowance of damages for the suffered prejudice, regardless if that is a physical, moral or material one (art. 388 of the New Civil Code).

The last aspect of the same category of payments is the one based on the right of allowance. This obligation also existed in the past, presently being independent of culpability (the culpable one can solely benefit from it but only for a year since the decomposition of the marriage). The allowance cannot coexist with the compensation but is distinct and can be awarded in parallel with the damages linked to the aforementioned prejudice ${ }^{22}$ caused by the decomposition of marriage.

\section{Conclusions}

Such measures come to support the situation of the spouses that try to exit the vicious circle of an abusive marriage. It is evident that these norms are not perfect and can be improved upon, even though there are numerous aspects in question even in this phase of the

\footnotetext{
${ }^{20}$ Cristiana-Mihaela Crăciunescu, Mihaela-Gabriela Berindei, Convenția matrimonială. Considerații critice in Noul Cod civil. Comentarii, IIIrd edition, "Universul Juridic” Publishing House, 2011, p. 392-430.

${ }^{21}$ Noul Cod civil. Comentariu pe articole, coord. Fl. A. Baias etc., C.H. Beck Publishing House, 2012, p. 425431.

${ }^{22}$ Idem, p. 421-424.
} 
theoretical analysis. The practice will surely reveal new problems. It is evident that these norms must be perfected with more efficient prevention measures and with the application of the norms strictly regarding domestic violence.

These norms do not represent the perfect solution. However, they are very good premises for obtaining a real financial independence by those abused when this is the reason for their deterrence, contributing to the growth of the security of these persons. Also, these norms also assume the implementation of mid and long-term solutions that will assure the surpassing the difficult period of time for the abused person, after surpassing the critical moment of maximum urgency. In the lack of such certainties and of the convergence of all these factors, we all know that the "relapse" of the aggressor is very possible and especially the relapse of the victim, that enters in that spiral of dependency about which the psychologists talk about, the surpassing of the vicious circle being a complex process which must combine all these factors (psychological, economical, juridical, social).

The provisions at hand come to adequately complete the norms that regulate the prevention and sanctioning of the abuses. In the situation of a complete combination of social and psychological assistance (according to the legal provisions) with a juridical one, both of an optimal quality, there are real chances for stopping the abuses or at least minimalizing their effects on the victim and assuring at the same time a normal life for the future.

Compared to the old provisions, these novelties, both the Penal and Civil ones are absolutely innovating and welcomed.

\section{Bibliography}

Corina Buzdugan, Theories of the Right of the State to Impose the Legal Sanction in Criminal Matters în The Efficiency of Legal Norms, Hamangiu Publishing House, Bucharest, 2012;

Fl. A. Baias (coord.) etc., Noul Cod civil. Comentariu pe articole, C.H. Beck Publishing House, 2012;

Mirela Gorunescu, 13th of July 2012 http://www.juridice.ro/209698/ordinul-deprotectie-in-legislatia-romaneasca.html consulted on the $9^{\text {th }}$ of Oct. 2012;

Otilia Sava, on the 31st of March 2012

http://www.avocatnet.ro/content/articles/id_28240/De-ce-acceptam-violenta-domestica.html consulted on the $9^{\text {th }}$ of Oct. 2012;

http://www.ziare.com/stiri/violenta/un-sfert-din-femeile-si-copiii-din-europa-victimeale-violentei-1148779 - article and statistics from the $3^{\text {rd }}$ of Feb. 2012 consulted on the $9^{\text {th }}$ of Oct. 2012;

http://www.mmuncii.ro/pub/imagemanager/images/file/Statistica/Buletin\%20statistic/ 2009/familie1_65.pdf - consulted on the $9^{\text {th }}$ of Oct. 2012;

http://www.mmuncii.ro/pub/imagemanager/images/file/Statistica/Buletin\%20statistic/ 2009/familie4_68.pdf - consulted on the $9^{\text {th }}$ of Oct. 2012;

http://www.ziare.com/stiri/violenta/romania-peste-11-000-de-cazuri-de-violenta-infamilie-in-2010-1136095 - consulted on the $9^{\text {th }}$ of Oct. 2012;

http://www.ziare.com/stiri/violenta/jumatate-dintre-romani-considera-ca-violenta-

fizica-in-familie-este-ceva-normal-1087884 - article featured on the $12^{\text {th }}$ of Apr. 2011, consulted on the $8^{\text {th }}$ of Oct. 2012;

http://www.politiaromana.ro/prevenire/ - consulted on the $8^{\text {th }}$ of Oct. 2012;

http://www.telegrafonline.ro/1339448400/articol/201992/victimele_violentei_in_famil ie_cer_protectie_impotriva_agresorilor.html consulted on the $8^{\text {th }}$ of Oct. 2012.

Corina Buzdugan, Teoria generală a dreptului, "Universul Juridic" Publishing House, Bucharest, 2011; 
Cristiana-Mihaela Crăciunescu, Mihaela-Gabriela Berindei, Convenția matrimonială. Considerații critice în Noul Cod civil. Comentarii, $3^{\text {rd }}$ edition, "Universul Juridic" Publishing House, 2011;

Mariana Narcisa Radu, Mihnea Radu, The Concept of „Family Member” in the Romanian Penal Legislation in Valahia University Law Study, vol. XVIII, no. 2, 2011;

Maria Pescaru, Preventing and Fighting against (intra)Family Violence in Agora International Journal of Juridical Sciences, 2011;

Călina Jugastru, Reflecții asupra noțiunii şi evoluției drepturilor personalității, An. Inst. de Ist. "G. Barițiu”, Cluj-Napoca, Series Humanistica, vol. V, 2007;

Mariana Narcisa Radu, Mihnea Radu, Considerații privind legea pentru prevenirea şi combaterea violenței în familie în Studii şi cercetări din domeniul ştiințelor socio-umane, Cluj-Napoca Branch of Romanian Academy, vol. 12, Argonaut Publishing House, ClujNapoca, 2004. 